Copyright by the Ecological Society of America. E. N Jack Brookshire, H. Maurice Valett, Steven A. Thomas, and Jackson R. Webster 2005. COUPLED CYCLING OF DISSOLVED ORGANIC NITROGEN AND CARBON IN A FOREST STREAM. ECOlOgY 86:2487-2496. http:// dx.doi.org/10.1890/04-1184

Ecology, 86(9), 2005, pp. 2487-2496

(C) 2005 by the Ecological Society of America

\title{
COUPLED CYCLING OF DISSOLVED ORGANIC NITROGEN AND CARBON IN A FOREST STREAM
}

\author{
E. N. Jack Brookshire, ${ }^{1,3}$ H. Maurice Valett, ${ }^{1}$ Steven A. Thomas, ${ }^{2}$ And Jackson R. Webster ${ }^{1}$ \\ ${ }^{1}$ Department of Biology, Virginia Polytechnic Institute and State University, Blacksburg, Virginia 24061 USA \\ ${ }^{2}$ Department of Ecology and Evolutionary Biology, Cornell University, Ithaca, New York 14853 USA
}

\begin{abstract}
Dissolved organic nitrogen (DON) is an abundant but poorly understood pool of $\mathrm{N}$ in many ecosystems. We assessed DON cycling in a N-limited headwater forest stream via whole-ecosystem additions of dissolved inorganic nitrogen (DIN) and labile dissolved organic matter (DOM), hydrologic transport and biogeochemical modeling, and laboratory experiments with native sediments. We sampled surface and subsurface waters to understand how interaction among hydrologic exchange, DIN, DON, and dissolved organic carbon (DOC) influence stream $\mathrm{N}$ losses at summer baseflow. Added DON was taken up rapidly from the water column at rates exceeding DOC and DIN. A significant fraction of this DON was mineralized and nitrified. Combined DON and $\mathrm{NO}_{3}-\mathrm{N}$ uptake lengths resulted in spiraling lengths of $\sim 210 \mathrm{~m}$, suggesting the potential for multiple transformations of labile $\mathrm{N}$ loads within catchment boundaries. Simultaneous addition of DIN increased DOM uptake, but more so for C, resulting in an upward shift in the C:N ratio of uptake. Sediment incubations also showed a strong biotic influence on DOC and DON dynamics. Despite efficient uptake of added DOM, background DON and high molecular mass DOC concentrations increased downstream, resulting in higher DOM loads than could be accounted for by groundwater discharge and suggesting net release of less bioavailable forms from the channel/hyporheic zone. At the same time, subsurface DOM was characterized by very low $\mathrm{C}: \mathrm{N}$ ratios and a disproportionately large DON pool despite rapid hydrologic mixing with dilute and high $\mathrm{C}: \mathrm{N}$ ratio surface waters. Analysis of expected DON loads from conservative hyporheic fluxes indicated that watershed losses of DON would have been seven times greater in the absence of apparent benthic demand, suggesting tight internal cycling of subsurface DON. Our study further demonstrates the potential for significant transformation of $\mathrm{N}$ in headwater streams before export to downstream ecosystems.
\end{abstract}

Key words: cycling; dissolved organic carbon; dissolved organic nitrogen; forest stream; headwater catchment; hydrologic losses; nutrient uptake; spiraling.

\section{INTRODUCTION}

Nitrogen (N) availability can control biological activity from cells to ecosystems. For stream ecosystems, the balance between biotic demand and hydrologic transport determines the relative retention of N. Within small watershed ecosystems (sensu Likens and Bormann 1995), streams are the last step in the hydrologic continuum extending from the atmosphere through terrestrial and aquatic subsystems, and thus the final opportunity for biotic regulation of $\mathrm{N}$ before transport to downstream ecosystems. Headwater streams are biogeochemically responsive to $\mathrm{N}$, exhibiting rapid uptake of dissolved inorganic N (DIN; Peterson et al. 2001) and may also act as DIN transformers by affecting the relative abundance of $\mathrm{N}$ forms comprising total dissolved nitrogen (TDN).

Nitrogen demand in forest streams, as in forest soils (Currie 1999), is strongly linked to microbial cycling

Manuscript received 26 July 2004; revised 17 January 2005; accepted 25 January 2005. Corresponding Editor: S. Findlay.

${ }^{3}$ E-mail: ebrooksh@vt.edu of $\mathrm{N}$ contained in organic matter (Triska et al. 1984). In streams, dissolved organic matter (DOM) often constitutes the largest component of the organic matter pool (McKnight et al. 2003) and its flux from rivers often dominates organic loading to estuaries (Seitzinger and Sanders 1997). Dissolved organic N (DON) represents a major pool of dissolved $\mathrm{N}$ in many unpolluted headwater catchments (Triska et al. 1984, Lewis 2002, Perakis and Hedin 2002) but it is unclear to what extent $\mathrm{N}$ demand in streams is satisfied through accessing the $\mathrm{N}$ bound in DOM. Much of the DON in streams is believed to originate from soil as refractory humic and fulvic acids (Qualls and Haines 1991, 1992) and thus may behave conservatively along catchment flow paths (Hedin et al. 1995). Alternatively, forest streams are known to be major generators of dissolved organic carbon (DOC) via microbially mediated leaching of terrestrial detritus (Meyer et al. 1998). Production of DON may be high in forest streams as reflected in large differences in microbial and detrital C:N stoichiometry (Caraco and Cole 2003). Internally produced DON may constitute a relatively fast-turnover com- 
partment of $\mathrm{N}$ relative to terrestrial sources and thus an important part of the $\mathrm{N}$ economy of forest streams.

The importance of DON to biotic $\mathrm{N}$ uptake should vary with the degree of $\mathrm{N}$ limitation and DOM quality (Kaushal and Lewis 2003, Neff et al. 2003). Amino acids and other monomers are a small proportion of DOM in surface waters (McKnight et al. 2003), but are the most rapidly consumed forms of DOM in stream sediments (Fiebig 1997, Findlay and Sinsabaugh 2003). They thus represent a labile end member capable of playing a disproportionate role in ecosystem metabolism and transformation of $\mathrm{N}$.

In streams, the downstream advection of water imparts a spatial dimension to nutrient cycling. This dimension has been described in terms of spiraling length $(S)$ : the distance over which a nutrient transforms from inorganic to organic and back to inorganic form (Webster and Patten 1979, Newbold et al. 1981). Diffusive and capillary forces dictate flow and organize nutrient cycling in unsaturated soils (Wagener et al. 1998) such that residence times are long and transport distances are minimized. In contrast, streams are dominated by advective transport, though zones of relatively slow water movement can have strong influences on system biogeochemistry (Triska et al. 1989, Thomas et al. 2003).

In this study, we examined DON dynamics in surface and subsurface zones of a low DOC, N-limited forest stream via experimental additions of DIN and labile DOM at summer baseflow. Our central objective was to assess how the coupled spiraling of $\mathrm{C}$ and $\mathrm{N}$ translates into stream ecosystem $\mathrm{N}$ fluxes. We hypothesized that in N-limited streams, benthic biota should be capable of significant uptake and transformation of DON, but demand should be mediated by DIN and DOC availability and DOM quality. We tested these hypotheses with experiments addressing how hydrologic exchange, $\mathrm{N}$ availability, and DOM quality interact to affect whole-stream $\mathrm{N}$ cycling and dissolved $\mathrm{N}$ losses.

\section{Methods \\ Study site}

We conducted this research in Hugh White Creek (HWC), a second-order stream draining a 61-ha catchment in the Coweeta Hydrologic Laboratory in the Appalachian Mountains of southwestern North Carolina, USA. Climate is humid marine with moderate mean annual temperature $\left(13^{\circ} \mathrm{C}\right)$ and $>90 \%$ annual precipitation $(187 \mathrm{~cm})$ occurring as rain. Catchment vegetation is dominated by mixed oak, hickory, and tulip poplar forest, with birch and hemlock along streamsides (Webster et al. 1997). A dense understory of rhododendron shades many sections of the stream, resulting in $<5 \%$ incident light. Low gross primary production $(\sim 6$ $\left.\mathrm{g} \cdot \mathrm{m}^{-2} \cdot \mathrm{yr}^{-1}\right)$ and high input of terrestrial detritus $(\sim 600$ $\left.\mathrm{g} \cdot \mathrm{m}^{-2} \cdot \mathrm{yr}^{-1}\right)$ result in a highly heterotrophic ecosystem (Webster et al. 1997). Stream water is characterized by low concentrations of DOC $(<1 \mathrm{mg} / \mathrm{L})$ and inorganic $\mathrm{N}(<20 \mu \mathrm{g} / \mathrm{L})$ and phosphorus $(<2 \mu \mathrm{g} / \mathrm{L})$ (Munn and Meyer 1990, Swank and Vose 1997). Channel sediments are dominated by gravels and cobbles, interspersed with sand and bedrock outcrops. Catchment soils are underlain by deep saprolite, which is thought to be the primary source of baseflow (Velbel 1988). HWC has remained undisturbed since 1924 and is a reference site for long-term hydrologic and chemical monitoring (Swank and Vose 1997).

\section{Experimental design and instrumentation}

We combined three complementary approaches to study DON cycling in HWC: (1) whole-stream additions of nitrate $\left(\mathrm{NO}_{3}-\mathrm{N}\right)$ and/or labile DOM, (2) hydrological and biogeochemical modeling, and (3) laboratory experiments with native stream sediments amended with labile DOM. The study reach on the main channel of HWC extended $\sim 700 \mathrm{~m}$ upstream of a weir at the base of the watershed. In 1999, we established well transects for sampling subsurface water chemistry located at $69,95,110$, and $159 \mathrm{~m}$ below the head of the reach. Transects were composed of 3 to 4 wells distributed across the wetted channel width. Wells ( $n$ $=15$ ) consisted of 5-cm PVC casings (closed bottom) with $15-\mathrm{cm}$ length slotted screens $(254-\mu \mathrm{m}$ slot) inserted $\sim 25 \mathrm{~cm}$ beneath the channel bottom.

\section{Additions of $\mathrm{NO}_{3}-\mathrm{N}$ and $\mathrm{DOM}$}

Nutrient enrichment experiments were conducted from 19-21 July 2003 and consisted of sequential individual additions of (1) $\mathrm{NaNO}_{3}$, (2) urea, (3) glutamic acid, and (4) glutamic acid $+\mathrm{NaNO}_{3}$. We used glutamic acid and urea because they differ in $\mathrm{C}: \mathrm{N}$ mass ratio and molecular mass (L-glutamic acid, Sigma-Aldrich G2128, C:N $=4.3$, MW = 147; urea, Sigma-Aldrich U0631, C:N = 0.43, MW = 60; Sigma-Aldrich, St. Louis, Missouri, USA), and thus potentially in bioavailability. The glutamic acid $+\mathrm{NaNO}_{3}$ addition was conducted to assess effects of elevated DIN on DON and DOC uptake.

All solutes were dissolved in deionized water with $\mathrm{NaCl}$ as a conservative tracer added to elevate $\mathrm{Cl}^{-}$concentration $3 \mathrm{mg} / \mathrm{L}$ above background $(\sim 0.55 \mathrm{mg} / \mathrm{L})$ and increase electrical conductivity $\sim 12 \mu \mathrm{S}$. Background $\mathrm{NO}_{3}-\mathrm{N}$ varied from 3 to $20 \mu \mathrm{g} / \mathrm{L}$ and a $\mathrm{NaNO}_{3}$ solution was used to elevate $\mathrm{N}$ concentration by $50 \mu \mathrm{g} / \mathrm{L}$. DOM was added to elevate stream DON by $300 \mu \mathrm{g}$ N/L above background (15-80 $\mu \mathrm{g} \mathrm{N} / \mathrm{L})$, an enrichment that allowed quantification of $\mathrm{N}$ and $\mathrm{C}$ above background variability for both DOM forms. Nutrient additions temporarily elevated $\mathrm{N}: \mathrm{P}$ ratios above that characteristic of baseflow conditions. Additions resulted in a DOC enrichment of $1290 \mu \mathrm{g}$ C/L for glutamic acid and $129 \mu \mathrm{g} \mathrm{C} / \mathrm{L}$ for urea.

Prior to the initial addition, we placed datalogger mini-sondes (HydroLab, Austin, Texas, USA) at 200 (immediately upstream of a small tributary), 300, and 
$650 \mathrm{~m}$ downstream of the addition site. Sondes recorded specific electrical conductance every $4 \mathrm{~min}$. Background stream water samples $(n=4)$ were collected prior to each nutrient release at eight longitudinally distributed stations: $-5 \mathrm{~m}$ (upstream reference site), 30, 60, 90, 150, 220, 300, and $650 \mathrm{~m}$ downstream of the addition site. Hyporheic water was sampled in all wells $(n=15)$ prior to the initial $\mathrm{NaNO}_{3}$ release and at one well from each of four transects prior to subsequent releases using screened vinyl tubing and a syringe. Samples were filtered (Whatman GF/F, pore size $=0.7 \mu \mathrm{m}$ ) into acid-washed $125-\mathrm{mL}$ polyethylene bottles and frozen until analyzed for $\mathrm{NO}_{3}-\mathrm{N}, \mathrm{NH}_{4}-\mathrm{N}$, DON, and DOC. Specific conductance, temperature, and dissolved oxygen (DO) were recorded at each station and in each well using YSI conductivity and DO meters (YSI, Yellow Springs, Ohio, USA).

Nutrients were pumped from individual carboys using a fluid metering pump (FMI, Syosset, New York, USA) and delivered to a well-mixed location in the stream at $25 \mathrm{~mL} / \mathrm{min}$ for $\sim 5 \mathrm{~h}$. Additions were conducted on different days, separated by $>18$ h to ensure adequate hydrologic flushing. During each release, we tracked $\mathrm{Cl}^{-}$by monitoring specific conductance at the 300 -m station until the signal stabilized $(\sim 3.5 \mathrm{~h})$. We then sampled during the "plateau" as described for background sampling. After sampling during the glutamic acid release (day 3 ), the addition was allowed to continue while a second pump simultaneously introduced $\mathrm{NaNO}_{3}$ to the stream. We sampled wells simultaneously with stream sampling during $\mathrm{NaNO}_{3}$ and glutamic acid $+\mathrm{NaNO}_{3}(n=4$ wells $)$ and urea and glutamic acid additions ( $n=10$ wells).

\section{Hydrology and transient storage modeling}

Stream discharge $(Q=\mathrm{L} / \mathrm{s})$ was determined using dilution gauging techniques (Webster and Ehrman 1996). Stream depth $(z)$ and width $(w)$ were measured at regular intervals along the $650-\mathrm{m}$ reach. We developed a standard curve relating specific conductance $(\mu \mathrm{S} / \mathrm{cm})$ to $\mathrm{Cl}^{-}$concentrations $(\mu \mathrm{g} / \mathrm{L})$ in the stream $\left(\mathrm{Cl}^{-}\right.$ $\left.=278.8 \mu \mathrm{S}-2408.7, r^{2}=0.99\right)$. Lateral inflow $\left(Q_{\mathrm{L}}\right.$, $\mathrm{L} \cdot \mathrm{m}^{-1} \cdot \mathrm{s}^{-1}$ ) was determined from longitudinal patterns of $\mathrm{Cl}^{-}$dilution. Hydrologic variables were determined by comparing numerical solutions of a one-dimensional advection-dispersion transport model that includes transient storage and lateral inflow (Bencala and Walters 1983) with observed $\mathrm{Cl}^{-}$concentrations using a model fit program similar to and in conjunction with OTIS-P (Runkel 1998).

Modeled variables included stream discharge $(Q)$, lateral inflow $\left(Q_{\mathrm{L}}, \mathrm{L} / \mathrm{s}\right)$, the coefficient of exchange between the stream channel and the transient storage zone $\left(\alpha, \mathrm{s}^{-1}\right)$, and the cross-sectional areas of the open channel and the theoretical transient storage zones $(A$ and $A_{\mathrm{s}}, \mathrm{m}^{2}$ ). Using model results, we calculated mean water velocity $(u=Q / A)$, uptake length for water $\left(L_{\mathrm{s}}\right.$ $=u / \alpha)$, mean storage zone water residence time $\left(T_{\mathrm{s}}=\right.$
$\left.A_{\mathrm{s}} / \alpha A\right)$, and the transient storage exchange flux $\left(q_{\mathrm{s}}=\right.$ $\alpha A)$ as described by Harvey and Wagner (2000). The upper 300-m reach of stream was used for hydrologic modeling because it included all well locations and most surface water transects. Percentage surface water in hyporheic wells was determined with a mixing model that compares change in $\mathrm{Cl}^{-}$concentrations in surface vs. well waters (Triska et al. 1989).

In February 2004 (during a period of similar flow as July 2003), we independently assessed the residence time of hyporheic water by injecting $\sim 2 \mathrm{~mL}$ of $\mathrm{NaCl}$ solution $\left(1 \mathrm{~g} \mathrm{Cl}^{-} / \mathrm{L}\right)$ into a subset of individual wells ( $n=8$, two per transect) and tracking $\mathrm{Cl}^{-}$clearance curves via exponential decay in specific conductance $\left(k_{\mathrm{c}}, \mathrm{h}^{-1}\right)$ over time $(\sim 2 \mathrm{~h})$. Mean water residence time (h) was calculated as $1 / k_{\mathrm{c}}$.

\section{Nutrient uptake, production, and transformation}

We estimated nutrient uptake lengths $\left(S_{w}\right.$; the average distance traveled by a reactive solute) as $1 / k_{\mathrm{L}}$, where $k_{\mathrm{L}}$ is the longitudinal loss rate $\left(\mathrm{m}^{-1}\right)$ determined with linear regressions of the natural $\mathrm{ln}$-transformed background-corrected plateau $\mathrm{N}: \mathrm{Cl}$ or $\mathrm{C}: \mathrm{Cl}$ ratios against distance downstream (Newbold et al. 1981). Uptake velocity $\left(v_{f}=Q / w S_{w}, \mathrm{~mm} / \mathrm{min}\right)$ and rate $\left(U=v_{f} C\right.$, $\left.\mathrm{mg} \cdot \mathrm{m}^{-2} \cdot \mathrm{d}^{-1}\right)$ were calculated to determine mass transfer and areal influxes of nutrients, where $w$ is mean stream width and $C$ is background concentration (Stream Solute Workshop 1990).

Mineralization of DON was estimated by fitting a two-compartment mass balance model to the longitudinal profile of added $\mathrm{DON}$ and $\mathrm{NO}_{3}-\mathrm{N}$ loads to produce best-fit estimates of simultaneous DON consumption $\left(k_{\mathrm{DON}}\right)$ and $\mathrm{NO}_{3}-\mathrm{N}$ production $\left(k_{\mathrm{NIT}}\right)$ and uptake $\left(k_{\mathrm{NO}_{3}}\right)$ following Mulholland et al. (2000). The preliminary step of ammonification of DON to $\mathrm{NH}_{4}-\mathrm{N}$ was ignored because we were unable to detect a $\mathrm{NH}_{4}-\mathrm{N}$ response in surface waters to DON additions. Nitrification fluxes were calculated as $k_{\mathrm{NIT}} / k_{\mathrm{DON}} \times U_{\mathrm{DON}}$ using the geometric mean of added longitudinal DON concentrations. We were unable to calculate nitrate uptake or nitrification for the glutamic acid + nitrate experiment because of source ambiguity of elevated $\mathrm{NO}_{3}-\mathrm{N}$. We assessed net consumption or production in the hyporheic zone by comparing observed background-corrected plateau $\mathrm{N}$ and $\mathrm{C}$ concentrations in wells vs. expected values derived from $\mathrm{Cl}^{-}$concentrations assuming conservative transport from the nearest upstream surface transect (sensu Triska et al. 1989, Valett et al. 1996).

We calculated "realized" production rates for chemicals that increased in concentration downstream (i.e., increases in load were greater than increases in discharge) by multiplying the up-to-downstream concentration difference by downstream $\mathrm{Q}$ and dividing the resultant load by total benthic surface area (Meyer et al. 1998). We also calculated "expected" loads based on conservative subsurface-to-surface nutrient fluxes using $q_{\mathrm{s}} C_{\mathrm{H}}+Q_{\mathrm{L}} C_{\mathrm{S}}$ adjusted for stream width, where 
$C_{\mathrm{H}}$ is the mean background hyporheic nutrient concentration for all well samples and $C_{\mathrm{S}}$ is the mean background stream nutrient concentration at the transect above the addition point. Expected stream loads were calculated by adding resultant hyporheic fluxes to stream loads derived from upstream surface water concentrations and $Q_{\mathrm{L}}$ (i.e., nutrient loads conservatively tracking water inputs).

\section{Laboratory microcosms}

We assessed the relative importance of biotic and abiotic uptake of DOM by conducting short-term batch incubation experiments. After field experiments, $\sim 2 \mathrm{~kg}$ of native sediments were collected from a tributary entering $\mathrm{HWC}$ at $200 \mathrm{~m}$ and were kept in the laboratory at $4^{\circ} \mathrm{C}$ until initiating microcosm assays ( $\left.3 \mathrm{~d}\right)$. Sediment was first reacclimated to ambient stream temperatures $\left(15^{\circ} \mathrm{C}\right)$ for $24 \mathrm{~h}$, sieved (1-cm mesh), and homogenized. To eliminate biotic activity, half of the sediments were saturated with a solution of $\mathrm{HgCl}_{2}(100 \mathrm{mg} / \mathrm{L}$; Dahm $1981)$. We then added $50 \mathrm{~cm}^{3}(\sim 83 \mathrm{~g}, \sim 1 \% \mathrm{OM})$ of well-drained live or dead sediments into 500-mL flasks across three treatments: (1) deionized (DI) water (200 $\mathrm{mL}$ ), (2) DI water + urea, and (3) DI water + Lglutamic acid, with four replicates each $(n=24)$. We added $60 \mu \mathrm{L}$ of concentrated DOM to enrich water by $300 \mu \mathrm{g}$ DON/L. Water and water $+\mathrm{HgCl}_{2}$ controls were used to correct for background release of $\mathrm{C}$ and $\mathrm{N}$ from sediments. Flasks were shaken at $125 \mathrm{rpm}$ and $15^{\circ} \mathrm{C}$ for a total of $4 \mathrm{~h}$. At 0.5 and $4 \mathrm{~h}, \sim 30 \mathrm{~mL}$ of supernatant was drawn off for analysis. Samples were filtered $(\mathrm{GF} / \mathrm{F})$, stored in polyethylene bottles, and frozen. Uptake was analyzed as change in nutrient mass per gram of sediment.

\section{Analytical chemistry}

Nitrate-N was determined colorimetrically following the acidic diazo method after cadmium reduction (Wood et al. 1967) on a Technicon auto analyzer II (Technicon, Emeryville, California, USA). Ammonium- $\mathrm{N}$ was analyzed colorimetrically following an automated phenate method (Soloranzo 1969). Total dissolved N (TDN) was determined by high temperature potassium persulfate oxidation followed by analysis of nitrate. DON was calculated by difference as TDN $\left(\mathrm{NO}_{3}-\mathrm{N}+\mathrm{NH}_{4}-\mathrm{N}\right)$ using L-glutamic acid as a reference standard (D'Elia et al. 1977, APHA 1998). DOC was determined by sodium persulfate oxidation using a total organic carbon analyzer (Model 700, Oceanographic International, College Station, Texas, USA; Menzel and Vacarro 1964). A subset of background and plateau samples were analyzed for $\mathrm{Cl}^{-}$using a Dionex 500 ion chromatograph (Dionex, Atlanta, Georgia, USA) equipped with an AS14 anion detection column (APHA 1998). To assess large molecular mass humic substances, background samples were analyzed for specific ultraviolet absorbance (SUVA) at $254 \mathrm{~nm}$ using a 10-cm path cell in a Shimadzu spectrophotometer (Shimadzu, Tokyo, Japan; Chin et al. 1994).

\section{Statistical analysis}

Spatial patterns in background nutrients were analyzed with linear regressions of concentrations and fluxes with distance downstream. We tested for differences among uptake slopes $(k)$ of added nutrients by assessing the interaction term between distance downstream and added nutrient type with multiple linear regression (Zar 1984). We tested for differences between stream and hyporheic concentrations, expected and observed plateau hyporheic concentrations, and differences between live vs. dead sediment treatments using paired $t$ tests. We compared observed vs. expected increases in nutrient loads using chi-square analysis. All statistical tests were performed using SAS (SAS Institute 1997).

\section{RESUlTS \\ Hydrologic dynamics}

Discharge increased from 8.7 to $20.2 \mathrm{~L} / \mathrm{s}$ over the first $300 \mathrm{~m}$ of study reach, representing a lateral inflow rate of $0.016 \mathrm{~L} \cdot \mathrm{s}^{-1} \cdot \mathrm{m}^{-1}$. At the same time, results from transient storage modeling (Appendix A) showed that the transient storage exchange flux $\left(q_{\mathrm{s}}\right)$ was 0.052 $\mathrm{L} \cdot \mathrm{s}^{-1} \cdot \mathrm{m}^{-1}$, suggesting that $>3$ times the volume of water was exchanged with transient storage than was discharged from groundwater per length of stream channel. This relationship was mirrored by mixing within the hyporheic zone, where percentage surface water averaged $72.2 \pm 9.5 \%$ (mean $\pm \mathrm{SE}$ ) in sampling wells. The uptake length of water $\left(L_{\mathrm{s}}\right)$ was $417 \mathrm{~m}$, and $71 \%$ of all surface water was exchanged with the storage zone over the $300 \mathrm{~m}$ reach. Water residence time in transient storage $\left(T_{\mathrm{s}}\right)$ was $1.1 \mathrm{~h}$, a value very similar to that derived for hyporheic wells $(1.9 \pm 0.4 \mathrm{~h} ; n=$ $8)$. The relative size of the transient storage zone $\left(A_{\mathrm{s}} / A\right)$ was 0.8 .

\section{Background chemistry}

Stream water was well oxygenated and characterized by low concentrations of $\mathrm{NO}_{3}-\mathrm{N}(11 \pm 0.1 \mu \mathrm{g} / \mathrm{L})$ and $\mathrm{NH}_{4}-\mathrm{N}(2 \pm 0.3 \mu \mathrm{g} / \mathrm{L}$; Fig. 1$)$. Stream water DON concentrations were significantly $(P<0.01)$ higher than DIN and represented $\sim 65 \%$ of stream TDN (Fig. 1). Low DOC and high atomic $\mathrm{C}: \mathrm{N}$ ratios (range = 25-96; mean $\pm \mathrm{SE}=50 \pm 4$ ) characterized stream DOM. In contrast to stream water, hyporheic well water was significantly $(P<0.01)$ elevated in DIN $\left(\mathrm{NO}_{3}-\mathrm{N}\right.$ $\left.=33 \pm 7 \mu \mathrm{g} / \mathrm{L} ; \mathrm{NH}_{4}-\mathrm{N}=8 \pm 1 \mu \mathrm{g} / \mathrm{L}\right), \mathrm{DON}$, and DOC, and depleted in DO (Fig. 1). DON also dominated $(\sim 89 \%)$ TDN in the hyporheic zone. High DON and only moderately elevated DOC resulted in very low hyporheic DOM C:N ratios $(1.5-14.3 ; 6 \pm 1)$ compared to stream DOM. SUVA analysis of well samples $(n=4)$ indicated overlap between subsurface and sur- 

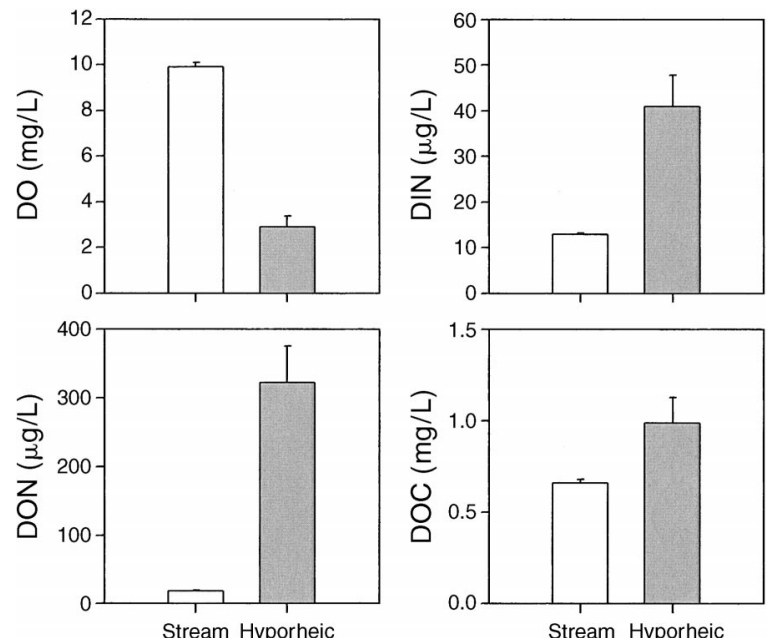

FIG. 1. Comparison of background stream and hyporheic water chemistry (mean $\pm \mathrm{SE}$ ): DO, dissolved oxygen; DON, dissolved organic nitrogen; DIN, dissolved inorganic nitrogen; DOC, dissolved organic carbon. Means were significantly $(P<0.01)$ different as determined by paired $t$ tests.

face values $\left(1.9 \pm 0.2\right.$ vs. $\left.2.0 \pm 0.1 \mathrm{~L} \cdot \mathrm{mg} \mathrm{C} \mathrm{C}^{-1} \cdot \mathrm{m}^{-1}\right)$. Although $\mathrm{NO}_{3}-\mathrm{N}$ concentrations were highest at the transect most downstream $(19.2 \pm 0.1 \mu \mathrm{g} / \mathrm{L})$, the regression with distance downstream was not significant $(P=0.56)$ without this point. In contrast, stream concentrations of DON and DOC and SUVA values increased significantly $(P<0.01)$ with distance downstream at both scales (Fig. 2). These results indicate greater increases in dissolved organic $\mathrm{C}$ and $\mathrm{N}$ loads than could be accounted for by increases in discharge, indicating an important channel/hyporheic source of nutrients other than groundwater.

\section{Nutrient uptake and transformation}

HWC exhibited strong and differential uptake of added DOM and DIN. DON was taken up at a significantly $(P<0.05)$ higher rate than either $\mathrm{NO}_{3}-\mathrm{N}$ alone or DOC within the DOM pool (Table 1). After correction for dilution, only $\sim 6 \%$ of added DON remained $300 \mathrm{~m}$ downstream of the addition site during the experimental additions. Longitudinal loss rates $\left(k_{\mathrm{L}}\right)$ for DOC and DON were similar $(P>0.05)$ between urea

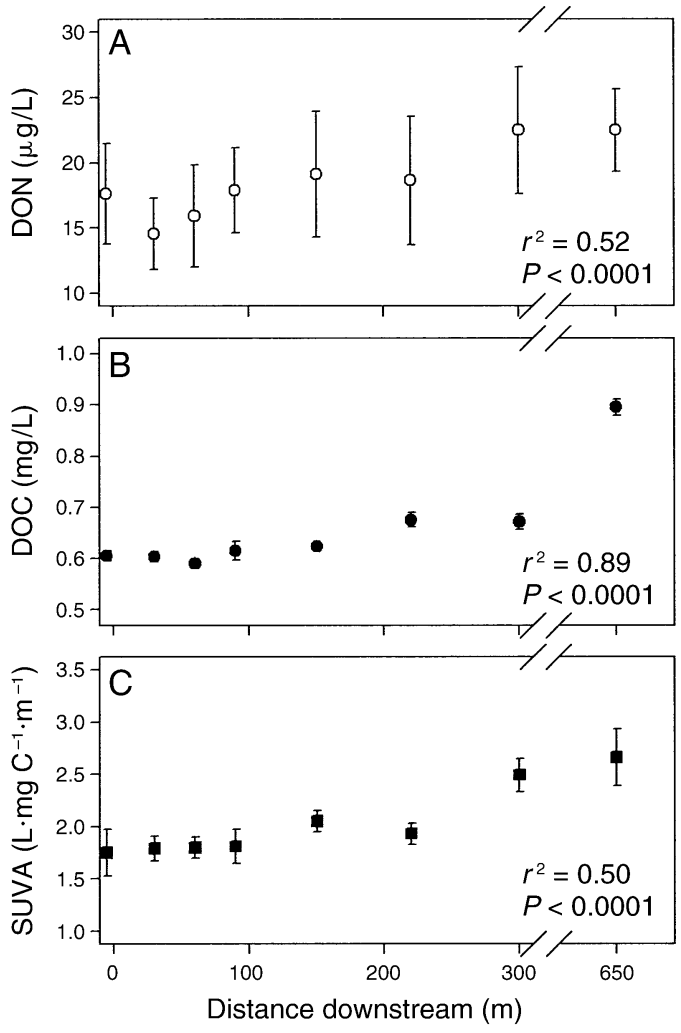

FIG. 2. Background longitudinal patterns in ambient stream (A) DON, (B) DOC, and (C) SUVA (specific ultraviolet absorbance) values in Hugh White Creek, North Carolina, USA. Data are means \pm SE $(n=4$ per location $)$. Statistics are from regressions of all samples against distance downstream. Regressions remained significant $(P<0.01)$ following removal of data for $650 \mathrm{~m}$.

and glutamic acid additions. Differential uptake of $\mathrm{C}$ and $\mathrm{N}$ during urea and glutamic acid additions resulted in mass ratios of $\mathrm{C}$ and $\mathrm{N}$ uptake $\left(k_{\mathrm{DOC}}: k_{\mathrm{DON}}\right)$ of 0.8 and 0.65 and areal $\mathrm{C}$ and $\mathrm{N}$ uptake $\left(U_{\mathrm{DOC}}: U_{\mathrm{DON}}\right)$ of 0.9 and 3.6, respectively. Addition of $\mathrm{NO}_{3}-\mathrm{N}$ during the glutamic acid experiment substantially increased uptake of DOC and DON (Table 1) but more so for C, thus shifting the stoichiometry of DOM uptake $\left(k_{\mathrm{DOC}}: k_{\mathrm{DON}}\right.$ $=1.2$ and $U_{\mathrm{DOC}}: U_{\mathrm{DON}}=6.5$ ).

Rapid nitrification of added DON resulted in significant $(P<0.01)$ increases in surface water $\mathrm{NO}_{3}-\mathrm{N}$ con-

TABLE 1. Spiraling metrics for experimental nutrient releases: longitudinal uptake coefficients $\left(k_{\mathrm{L}}\right)$, nutrient uptake lengths $\left(S_{\mathrm{w}}\right)$, uptake velocities $\left(v_{\mathrm{f}}\right)$, and areal uptake $(U)$.

\begin{tabular}{|c|c|c|c|c|c|c|c|}
\hline \multirow[b]{2}{*}{ Metric } & \multirow{2}{*}{$\begin{array}{c}\text { Nitrate } \\
\mathrm{N}\end{array}$} & \multicolumn{2}{|c|}{ Urea } & \multicolumn{2}{|c|}{ Glutamic acid } & \multicolumn{2}{|c|}{ Glutamic + Nitrate } \\
\hline & & DOC & DON & DOC & DON & DOC & DON \\
\hline$k_{\mathrm{L}}\left(\mathrm{m}^{-1}\right) \dagger$ & $0.0028^{a}$ & $0.0077^{\mathrm{b}}$ & $0.0096^{\mathrm{bc}}$ & $0.0065^{\mathrm{b}}$ & $0.0100^{c}$ & $0.0154^{\mathrm{d}}$ & $0.0123^{\mathrm{e}}$ \\
\hline$S_{\mathrm{w}}(\mathrm{m})$ & 357.1 & 129.9 & 104.2 & 153.8 & 100.0 & 64.9 & 81.3 \\
\hline$v_{\mathrm{t}}(\mathrm{mm} / \mathrm{min})$ & 0.60 & 1.65 & 2.06 & 1.39 & 2.14 & 3.31 & 2.64 \\
\hline$U\left(\mathrm{mg} \cdot \mathrm{m}^{-2} \cdot \mathrm{d}^{-1}\right)$ & 9.3 & 295.0 & 311.0 & 1155.0 & 324.0 & 2726.8 & 416.2 \\
\hline
\end{tabular}

$\dagger$ Different superscripted letters indicate significant $(P<0.05)$ differences among uptake coefficients $\left(k_{\mathrm{L}}\right)$.

$\ddagger$ Areal uptake is based on background concentrations for $\mathrm{NO}_{3}-\mathrm{N}$ and the geometric mean of added concentrations for dissolved organic carbon (DOC) and dissolved organic nitrogen (DON). 


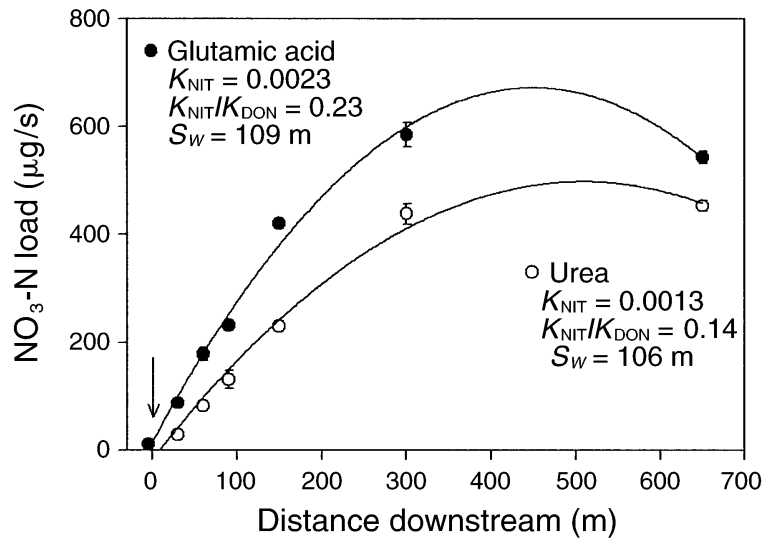

FIG. 3. Nitrate production curves during urea (open circles) and glutamic acid (solid circles) additions. Values are mean ( \pm SE) background-corrected nitrate loads. Included are results from the mass balance model for the longitudinal nitrification rate $\left(k_{\mathrm{NIT}}\right)$, the proportion of DON uptake nitrified $\left(k_{\mathrm{NIT}} / k_{\mathrm{DON}}\right)$, and simultaneous nitrate uptake lengths $\left(S_{w}\right)$. The arrow indicates the nutrient addition site.

centrations (Fig. 3). Although most DON was taken up within the first $300 \mathrm{~m}$, elevated $\mathrm{NO}_{3}-\mathrm{N}$ concentrations were evident at the base of the watershed $(650 \mathrm{~m})$. Extremely rapid and transitory ammonification was suggested by stable and low $\mathrm{NH}_{4}-\mathrm{N}$ concentrations in surface and subsurface waters during DOM releases. Nitrification rates accounted for $14 \%$ and $23 \%$ of ureaDON and glutamic acid-DON uptake, respectively (Fig. 3).

The mass balance model produced estimates of nitrate uptake lengths three times shorter than those calculated from the $\mathrm{NO}_{3}-\mathrm{N}$ addition (Fig. 3, Table 1). Adding DON and produced $\mathrm{NO}_{3}-\mathrm{N}$ uptake lengths resulted in a total $\mathrm{N}$ spiraling length $(S)$ of 209 and $210 \mathrm{~m}$. Combining all $S_{w}$ estimates for $\mathrm{NO}_{3}-\mathrm{N}$ indicated that background net uptake could have varied from 9 to 31 $\mathrm{mg} \mathrm{N} \cdot \mathrm{m}^{-2} \cdot \mathrm{d}^{-1}$. By comparison, net nitrification calculated using background and added DON levels varied from 7.4 to $46.9 \mathrm{mg} \mathrm{N} \cdot \mathrm{m}^{-2} \cdot \mathrm{d}^{-1}$.

Although we found rapid uptake of added DON in surface waters, analysis of hyporheic concentrations suggested that DON was transported conservatively to the hyporheic zone where observed and expected concentrations were not significantly different $(P=0.92$, paired $t$ tests; Fig. 4A). Concentrations of $\mathrm{NH}_{4}-\mathrm{N}$ did not differ between background and plateau samples $(P$ $>0.2$ ). During the same period, 22 out of 24 samples showed net production of $\mathrm{NO}_{3}-\mathrm{N}(P<0.001 ;$ Fig. 4B). In contrast, we found that the hyporheic zone was a net consumer of added DOC ( $P=0.047)$ in 18 of the 24 samples (Fig. 4C).

\section{Sediment microcosms}

Dissolved organic matter was released over time from killed (DOM C:N = 16) and live (DOM C:N = 25) control sediments. Background release of DON was greater $(P<0.05)$ in killed $(3.1 \pm 0.5 \mu \mathrm{g} \mathrm{N} / \mathrm{g}$ sediment $)$ vs. live $(1.4 \pm 0.3 \mu \mathrm{g} \mathrm{N} / \mathrm{g}$ sediment) controls (Appendix B). Release of DOC was also greater $(P<0.05)$ in killed vs. live sediments but concentrations decreased in live sediments and accumulated in killed
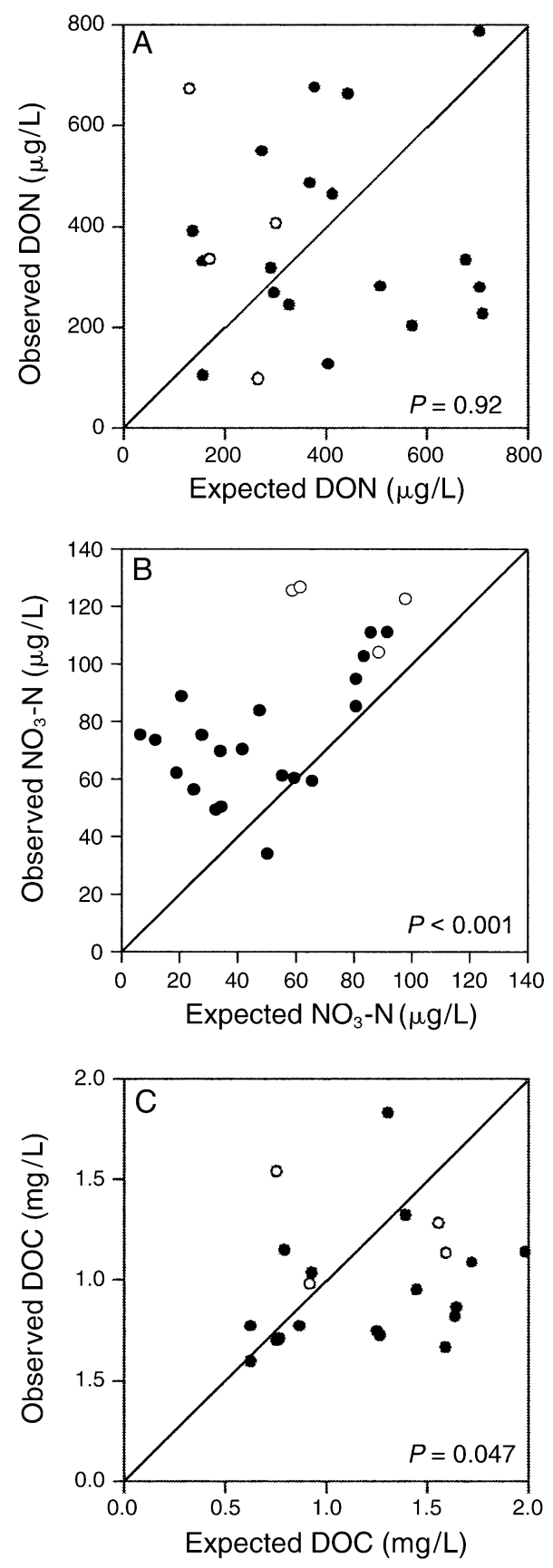

FIG. 4. Subsurface responses to both urea and glutamic acid additions (solid circles) and glutamic $+\mathrm{NO}_{3}-\mathrm{N}$ (open circles) showing (A) DON, (B) production of $\mathrm{NO}_{3}-\mathrm{N}$, and (C) consumption of DOC. Values above the 1:1 observed-expected line indicate net production, while values below the line indicate net consumption. $P$ values are for results of paired $t$ tests. 


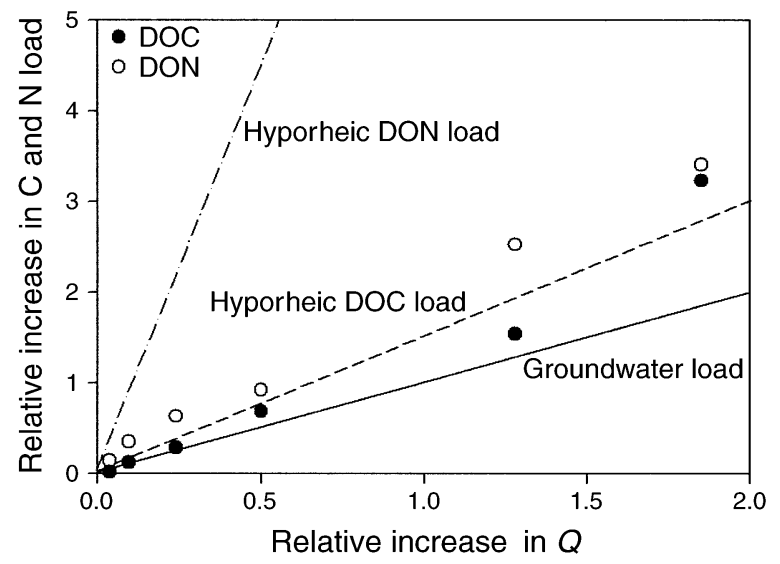

FIG. 5. Increase in DOC and DON load vs. increase in water load ( $Q$, stream discharge). Values represent the proportional increase in nutrient load at downstream transects relative to loads at the transect most upstream. The solid line represents the proportional increases in discharge and expected nutrients if nutrient loads tracked groundwater inputs (1:1 line). Dashed lines represent expected DOC and DON loads based on conservative transport of hyporheic concentrations.

sediments over time. All live treatments tended toward net consumption of added DOC and DON compared with net production in killed treatments, but differences were significant only for glutamic acid and control DOC treatments (Appendix C). Nitrification in live sediments was indicated by increases $(P<0.01)$ in $\mathrm{NO}_{3}^{-}$ $\mathrm{N}$ but constant $\mathrm{NH}_{4}-\mathrm{N}$ levels. In contrast, $\mathrm{NH}_{4}-\mathrm{N}$ accumulated in killed treatments (Appendix B).

\section{Stream fluxes and watershed losses}

Downstream increases in concentration (Fig. 2) translated to net production of DOC $\left(79.4 \mathrm{mg} \cdot \mathrm{m}^{-2} \cdot \mathrm{d}^{-1}\right)$ and DON $\left(2.1 \mathrm{mg} \cdot \mathrm{m}^{-2} \cdot \mathrm{d}^{-1}\right)$. However, observed increases in DON load were significantly lower $\left(\chi^{2}=\right.$ 24.3, $P<0.001)$ than expected based on conservative hyporheic fluxes (Fig. 5). Export of DON from the study reach would have been seven times greater than the observed $50 \mathrm{~g} / \mathrm{d}$ had hyporheic DON been transported conservatively to surface waters and downstream (i.e., $350 \mathrm{~g} / \mathrm{d}$ ). This translates to uptake of hyporheic DON of $478.2 \mathrm{mg} \cdot \mathrm{m}^{-2} \cdot \mathrm{d}^{-1}$ along the hyporheicstream flow path, similar to the mean observed uptake of experimentally added DON $\left(U_{\mathrm{DON}}=317.5\right.$ $\left.\mathrm{mg} \cdot \mathrm{m}^{-2} \cdot \mathrm{d}^{-1}\right)$. In contrast to apparent removal of DON, this analysis indicated subsurface DOC fluxes would result in loads equivalent $\left(\chi^{2}=0.4, P>0.25\right)$ to realized loads.

\section{DisCUSSION}

\section{Passive hydrologic transport vs. tight internal cycling of organic nutrients}

Our study provides evidence for whole-stream uptake and transformation of labile DON and indicates multiple potential interactions of DOC and DON in forest streams. Despite rapid uptake of added DOM, we found that the stream was a net producer of DOC and DON, resulting in watershed losses greater than expected from groundwater alone. Differential patterns of $\mathrm{C}$ and $\mathrm{N}$ uptake and production indicate that hydrologic exchange and biotic demand in forest streams can significantly influence watershed $\mathrm{N}$ losses.

Coweeta streams are strongly N-limited in part due to extremely low hydrologic $\mathrm{N}$ losses from surrounding forest ecosystems (Swank and Vose 1997). Our study showed pronounced uptake of monomeric DON and DOC in HWC, suggesting strong biotic demand for DOM in the face of low ambient $\mathrm{N}$ and $\mathrm{C}$ availability. Uptake lengths of DOC and DON were similar to that reported for a sucrose addition to HWC (Munn and Meyer 1990) but were longer than those observed for ${ }^{13} \mathrm{C}$-acetate additions $(\sim 10 \mathrm{~m})$ in other Coweeta streams (Hall and Meyer 1998). Further, addition of $\mathrm{NO}_{3}-\mathrm{N}$ during the glutamic acid experiment showed that uptake of labile DOM, especially DOC, is highly responsive to DIN availability. Together, these observations suggest that DON uptake was mediated by demand for DOC and in turn $\mathrm{C}$ demand was mediated by DIN. The shift in the C:N stoichiometry of uptake resulting from addition of DIN illustrates enhanced $\mathrm{C}$ uptake at times of high $\mathrm{N}$ availability. Accordingly, it also suggests higher labile DON demand in the face of lower DIN availability. These results support the idea of a strong link between inorganic $\mathrm{N}$ dynamics and DOC availability (Bernhardt and Likens 2002) and tight coupling of DOC, DIN, and DON spiraling in forest streams. Combined uptake lengths for DON and $\mathrm{NO}_{3}-\mathrm{N}$ indicate that multiple complete $\mathrm{N}$ transformations may occur along the stream reach. Our results support the notion that low abundance of labile DOM in surface waters may in part be a function of internal biotic demand by microbial biofilms (Kaplan and Newbold 2003, Battin et al. 2003) and are consistent with the idea that much of aquatic metabolism is supported by rapid turnover of low molecular mass DOM (Kirchman 2003).

In small streams, efficient biotic uptake of dissolved nutrients is associated with longer water residence times. Modeling and field measurements demonstrated strong surface-subsurface water exchange in HWC. Hydrologic exchange with longer residence time compartments is a key driver of DIN dynamics in many stream ecosystems (Triska et al. 1989, Valett et al. 1996, Thomas et al. 2003). We found the relationship between the transient storage exchange flux $\left(q_{\mathrm{s}}\right)$ and lateral inflow $\left(Q_{\mathrm{L}}\right)$ to be particularly useful for studying DON dynamics. Similar potential for DON transformation likely exists in other streams given that hydrologic metrics calculated for HWC are in the middle of published values for a variety of streams (Runkel 2002).

Large subsurface $\mathrm{N}$ pools exist despite rapid hydrologic mixing with dilute surface waters, suggesting in- 
ternal production. Indeed, DON concentrations are generally higher in subsurface vs. surface waters across a broad range of headwater forest streams in the southern Appalachian Mountains (E. N. J. Brookshire, unpublished data). Concentrations of DOC and DON decline with depth in mineral soils via rapid adsorption (Qualls and Haines 1991), resulting in near-stream groundwater DOM similar to stream water (Meyer and Tate 1983, Qualls and Haines 1991, Golladay et al. 1992), implying that groundwater inflow could not have produced elevated hyporheic DON concentrations. Further, conservative three-compartment (surface, hyporheic, and groundwater) mixing analysis (sensu Mulholland and Hill 1997) indicated that, given the high level of surface-subsurface mixing compared to lateral inputs, groundwater DON would have had to be unrealistically high $(\geq 1310 \mu \mathrm{g} / \mathrm{L})$ to produce observed hyporheic concentrations (E. N. J. Brookshire, unpublished data). At the same time, longitudinal increases in stream DON concentrations indicate net DON release. Several possible mechanisms may explain these patterns. Most DOC and DON in soils and stream waters of Coweeta are found in refractory humic and fulvic acids (Qualls and Haines 1991, 1992), consistent with the high C:N ratio and elevated SUVA values (McKnight et al. 2003) of surface water DOM found in our study. Previous studies in HWC also found longitudinal increases in DOC and high molecular mass DOM (Meyer and Tate 1983). Further, work in Coweeta has identified channelstored terrestrial particulate organic matter (POM) as the primary source of the observed DOC (Meyer et al. 1998). This is consistent with our findings that expected DOC loads from hyporheic fluxes were indistinguishable from realized loads. Similar longitudinal increases in DON observed in our study and large benthic pools of particulate organic $\mathrm{N}\left(12.6 \mathrm{~g} / \mathrm{m}^{2}\right.$; Webster et al. 1997 , Tank et al. 2000) suggest DON production may also be linked to in-stream detrital-N, presumably via hydrolysis and leaching.

Although longitudinal increases in DON suggest net release of less bioavailable forms, convergence of our experimentally determined labile DON uptake with that required to balance conservative hyporheic fluxes argues for very high consumption of internally produced DON, otherwise watershed losses would have been much higher. The low C:N ratios of hyporheic DOM observed in HWC were similar to microbial biomass (Tank et al. 2000), suggesting a microbial origin of hyporheic DON. Production and uptake of amino acids by heterotrophic bacteria is common and constitutes a major internal flow of energy and nutrients in lake and marine ecosystems (Kirchman 2003). Similarly, Fiebig (1997) demonstrated tight microbial recycling of amino acid-C in hyporheic sediments and Findlay and Sinsabaugh (2003) found comparable uptake of DIN and amino acid-N by hyporheic biofilms and widespread capacity for DON uptake across bacterial taxa. Our sediment experiments also showed a strong biotic in- fluence on amino acid-N uptake and revealed a large pool of DON in stream sediments.

Given close coupling of particulate and dissolved organic forms (sensu Meyer et al. 1998), increasing $\mathrm{N}$ content of POM associated with decomposition and $\mathrm{N}$ immobilization could also influence low $\mathrm{C}: \mathrm{N}$ ratios of DOM. Tank et al. (2000) found minimal labeling of surface water DON during a ${ }^{15} \mathrm{~N}-\mathrm{NH}_{4}$ addition to a nearby Coweeta stream, implying slow turnover of most surface water DON relative to transport. However, mass balance of ${ }^{15} \mathrm{~N}-\mathrm{NH}_{4}$ additions and others conducted with ${ }^{15} \mathrm{~N}-\mathrm{NO}_{3}$ in Coweeta $(\mathrm{H}$. M. Valett, unpublished data) generally yield $\sim 50 \%$ or less isotopic recovery, suggesting that some of the missing $\mathrm{N}$ may have gone to subsurface pools. Differential gaseous losses of $\mathrm{C}$ and $\mathrm{N}$ could also reduce $\mathrm{C}: \mathrm{N}$ ratios. Metabolic losses of $\mathrm{CO}_{2}$ are large in $\mathrm{HWC}$ (Webster et al. 1997) while $\mathrm{N}$ losses via denitrification are presumably much smaller. Increases in subsurface $\mathrm{NO}_{3}-\mathrm{N}$ and decreases in DOC during DOM experiments and only moderately elevated background DOC relative to surface water concentrations were also consistent with decreasing $\mathrm{N}$ limitation and increasing $\mathrm{C}$ limitation with depth, similar to hyporheic zones of other N-limited forest streams (Triska et al. 1989).

The large DIN pool in the hyporheic zone of HWC and rapid nitrification of added DON points to mineralization and subsequent benthic uptake as a potential fate of consumed DON. While we are aware that subsurface redox conditions and related $\mathrm{N}$ transformations can be very spatially heterogeneous (Baker et al. 2000), subsurface $\mathrm{N}$ accumulation and strong depletion of DO suggest that nitrification was mostly restricted to the benthic interface, and deeper subsurface concentrations of $\mathrm{NO}_{3}-\mathrm{N}$ were due to conservative transport of nitraterich infiltrating water. Microbial demand and regeneration appear to be equivalent, resulting in lack of longitudinal gradients in $\mathrm{NH}_{4}-\mathrm{N}$ and $\mathrm{NO}_{3}-\mathrm{N}$ concentrations in this stream. Further, the lack of an ammonification signal to DON additions is consistent with very rapid uptake of $\mathrm{NH}_{4}-\mathrm{N}$ in Coweeta streams (Hall et al. 1998, Tank et al. 2000). Conditions generated by our experiments may have restricted $\mathrm{NH}_{4}-\mathrm{N}$ cycling to the scale of the biofilm itself. Denitrification and downstream loss or deep burial as FPON, perhaps of biofilm origin, are also potential but poorly understood fates of dissolved $\mathrm{N}$.

Our study was conducted during summer baseflow when nutrient uptake is likely higher than during periods of high flow and colder temperatures. DOC concentrations and fluxes increase during storms relative to baseflow (Meyer and Tate 1983) and the same may apply to DON. Also, DIN uptake in Coweeta is highest after leaf-fall (H. M. Valett, unpublished data) reflecting increases in microbial demand associated with decomposition. Given the observed relationship between DON and DIN uptake, labile DON uptake may also increase during fall. However, stream $\mathrm{NO}_{3}-\mathrm{N}$ concen- 
trations and fluxes (Swank and Vose 1997) and subsurface DON concentrations (E. N. J. Brookshire, unpublished data) in Coweeta are highest during summer, suggesting a potentially important role of summer $\mathrm{N}$ cycling to annual watershed $\mathrm{N}$ losses.

Our results support the idea of an important role for DON production in forest streams (Caraco and Cole 2003). We propose two major pools of DON in HWC: (1) refractory DON derived primarily from catchment soils and secondarily from in-stream detrital leaching; and (2) labile internally recycled DON. This framework is consistent with fast and slow turnover pools described for stream DOM (Kaplan and Newbold 2003) and terrestrial DON (Neff et al. 2003). Our results suggest extremely short spiraling lengths for monomeric DON and much longer (i.e., at the scale of river networks) spiraling of complex, predominantly humic, terrestrial DON.

Large increases in global $\mathrm{N}$ availability via human activities (Vitousek et al. 1997) require better understanding of biotic controls on cycling of $\mathrm{N}$ at ecosystem scales. The results presented here argue for a much more influential role of stream biota in modulation of watershed DON losses than is commonly assumed. Our estimates of DIN and DON spiraling suggest that a significant portion of the dissolved $\mathrm{N}$ pool is transformed as it moves through headwater streams. Further, this study provides support for the idea that even small increases in DIN availability may alter ecosystem DOC and DON dynamics.

\section{ACKNOWLEDGMENTS}

We would like to thank Lenn Roberts and Johanna Barron for assistance in the field and Bobbie Niederlehner for assistance in the laboratory. Thoughtful reviews by Stuart Findlay and two anonymous reviewers improved this manuscript. This research was supported by NSF grant DEB 04-05373.

\section{Literature Cited}

APHA (American Public Health Association, American Water Works Association, Water Environment Federation). 1998. Standard methods for examination of water and wastewater. 20th edition. American Public Health Association, Washington, D.C., USA.

Baker, M. A., C. N. Dahm, and H. M. Valett. 2000. Anoxia, anaerobic metabolism, and biogeochemistry of the streamwater-ground-water interface. Pages $259-283$ in J. B. Jones and P. J Mulholland, editors. Streams and groundwaters. Academic Press, San Diego, California, USA.

Battin, T. J., L. A. Kaplan, J. D. Newbold, and C. M. E. Hansen. 2003. Contributions of microbial biofilms to ecosystem processes in stream mesocosms. Nature 426:439-442.

Bencala, K. E., and R. A. Walters. 1983. Simulation of solute transport in a mountain pool and riffle stream with a kinetic mass transfer model for sorption. Water Resources Research 19:718-724.

Bernhardt, E. S., and G. E. Likens. 2002. Dissolved organic carbon enrichment alters nitrogen dynamics in a forest stream. Ecology 83:1689-1700.

Caraco, N. F., and J. J. Cole. 2003. The importance of organic nitrogen production in aquatic systems: a landscape perspective. Pages 263-284 in S. E. G. Findlay and R. L. Sinsabaugh, editors. Aquatic ecosystems: interactivity of dissolved organic matter. Academic Press, San Diego, California, USA.
Chin, Y., G. Aiken, and E. O'Loughlin. 1994. Molecular weight, polydispersity, and spectroscopic properties of aquatic humic substances. Environmental Science and Technology 28:1853-1858.

Currie, W. S. 1999. The responsive C and $\mathrm{N}$ biogeochemistry of the temperate forest floor. Trends in Ecology and Evolution 14:316-320.

Dahm, C. D. 1981. Pathways and mechanisms of removal of dissolved organic carbon from leaf leachate in streams. Canadian Journal of Fisheries and Aquatic Sciences 38:68-76.

D'Elia, C. F., P. A. Steudler, and N. Corwin. 1977. Determination of total nitrogen in aqueous samples using persulfate digestion. Limnology and Oceanography 22:760764.

Fiebig, D. M. 1997. Microbiological turnover of amino acids immobilized from groundwater discharged through hyporheic sediments. Limnology and Oceanography 42:763768.

Findlay, S., and R. L. Sinsabaugh. 2003. Response of hyporheic biofilm metabolism and community structure to nitrogen amendments. Aquatic Microbial Ecology 33:127-136.

Golladay, S. W., J. R. Webster, E. F. Benfield, and W. T. Swank. 1992. Changes in stream stability following forest clearing as indicated by storm nutrient budgets. Archiv für Hydrobiologie Supplement 133:3-21.

Hall, R. O., and J. L. Meyer. 1998. The trophic significance of bacteria in a detritus-based stream food web. Ecology 79: 1995-2012.

Hall, R. O., B. J. Peterson, and J. L. Meyer. 1998. Testing a nitrogen-cycling model of a forest stream by using a nitrogen-15 tracer addition. Ecosystems 1:283-298.

Harvey, J. W., and B. J. Wagner. 2000. Quantifying hydrologic interactions between streams and their subsurface hyporheic zones. Pages 3-44 in J. B. Jones and P. J. Mulholland, editors. Streams and groundwaters. Academic Press, San Diego, California, USA.

Hedin, L. O., J. J. Armesto, and A. H. Johnson. 1995. Patterns of nutrient loss from unpolluted, old-growth temperate forests: evaluation of biogeochemical theory. Ecology 76: 493-509.

Kaplan, L. A., and J. D. Newbold. 2003. The role of monomers in stream ecosystem metabolism. Pages 97-120 in S. E. G. Findlay and R. L. Sinsabaugh, editors. Aquatic ecosystems: interactivity of dissolved organic matter. Academic Press, San Diego, California, USA.

Kaushal, S. S., and W. M. Lewis. 2003. Patterns in the chemical fractionation of organic nitrogen in Rocky Mountain streams. Ecosystems 6:483-492.

Kirchman, D. L. 2003. The contribution of monomers and other low-molecular mass compounds to the flux of dissolved organic material in aquatic ecosystems. Pages 217241 in S. E. G. Findlay and R. L. Sinsabaugh, editors. Aquatic ecosystems: interactivity of dissolved organic matter. Academic Press, San Diego, California, USA.

Lewis, W. M. 2002. Yield of nitrogen from minimally disturbed watersheds of the United States. Biogeochemistry 57/58:375-385.

Likens, G. E., and F. H. Bormann. 1995. Biogeochemistry of a forested ecosystem. Second edition. Springer-Verlag, New York, New York, USA.

McKnight, D. M., E. Hood, and E. Klepper. 2003. Trace moieties of dissolved organic material in natural waters. Pages 71-96 in S. E. G. Findlay and R. L. Sinsabaugh, editors. Aquatic ecosystems: interactivity of dissolved organic matter. Academic Press, San Diego, California, USA.

Menzel, D. W., and R. F. Vacarro. 1964. The measurement of dissolved organic and particulate carbon in seawater. Limnology and Oceanography 9:138-142.

Meyer, J. L., and C. M. Tate. 1983. The effects of watershed disturbance on dissolved organic carbon dynamics of a stream. Ecology 64:33-44. 
Meyer, J. L., J. B. Wallace, and S. L. Eggert. 1998. Leaf litter as a source of dissolved organic carbon in streams. Ecosystems 1:240-249.

Mulholland, P. J., and W. R. Hill. 1997. Seasonal patterns in streamwater nutrient and dissolved organic carbon concentrations: separating catchment flow path and in-stream effects. Water Resources Research 33:1297-1306.

Mulholland, P. J., J. L. Tank, D. Sanzone, W. M. Wollheim, B. J. Peterson, J. R. Webster, and J. L. Meyer. 2000. Nitrogen cycling in a forest stream determined by a ${ }^{15} \mathrm{~N}$ tracer addition. Ecological Monographs 70:471-493.

Munn, N. L., and J. L. Meyer. 1990. Habitat-specific solute retention in two small streams: an intersite comparison. Ecology 71:2069-2082.

Neff, J. C., F. S. Chapin, and P. M. Vitousek. 2003. Breaks in the cycle: dissolved organic nitrogen in terrestrial ecosystems. Frontiers in Ecology and the Environment 1:205-211.

Newbold, J. D., J. W. Elwood, R. V. O'Neill, and W. Van Winkle. 1981. Measuring nutrient spiralling in streams. Canadian Journal of Fisheries and Aquatic Sciences 38: 860-863.

Perakis, S. S., and L. O. Hedin. 2002. Nitrogen loss from unpolluted South American forests mainly via dissolved organic compounds. Nature 415:416-419.

Peterson, B. J., et al. 2001. Control of nitrogen export from watersheds by headwater streams. Science 292:86-90.

Qualls, R. G., and B. L. Haines. 1991. Geochemistry of dissolved organic nutrients in water percolating through a forest ecosystem. Soil Science Society of America Journal 55: 1112-1123.

Qualls, R. G., and B. L. Haines. 1992. Biodegradability of dissolved organic matter in forest through-fall, soil solution, and stream water. Soil Science Society of America Journal 56:578-586.

Runkel, R. L. 1998. One dimensional transport with inflow and storage (OTIS): a solute transport model for streams and rivers. U.S. Geological Survey Water Resources Investigation Report 98-4018. U.S. Geological Survey, Denver, Colorado, USA.

Runkel, R. L. 2002. A new metric for determining the importance of transient storage. Journal of the North American Benthological Society 21:529-543.

SAS Institute. 1997. SAS statistical software. Version 6.12. SAS Institute, Cary, North Carolina, USA.

Seitzinger, S. P., and R. W. Sanders. 1997. Contribution of dissolved organic nitrogen from rivers to estuarine eutrophication. Marine Ecology Progress Series 159:1-12.

Soloranzo, L. 1969. Determination of ammonia in natural waters by the phenolhypochlorite method. Limnology and Oceanography 14:799-801.

Stream Solute Workshop. 1990. Concepts and methods for assessing solute dynamics in stream ecosystems. Journal of the North American Benthological Society 9:95-119.
Swank, W. T., and J. M. Vose. 1997. Long-term nitrogen dynamics of Coweeta forested watersheds in the southeastern United States of America. Global Biogeochemical Cycles 11:657-671.

Tank, J. L., J. L. Meyer, D. M. Sanzone, P. J. Mulholland, J. R. Webster, B. J. Peterson, W. M. Wollheim, and N. E. Leonard. 2000. Analysis of nitrogen cycling in a forest stream during autumn using a ${ }^{15} \mathrm{~N}$-tracer addition. Limnology and Oceanography 45:1013-1029.

Thomas, S. A., H. M. Valett, J. R. Webster, and P. J. Mulholland. 2003. A regression approach to estimating reactive solute uptake in advective and transient storage zones of stream ecosystems. Advances in Water Resources 26: 965-976.

Triska, F. J., V. C. Kennedy, R. J. Avanzino, G. W. Zellweger, and K. E. Bencala. 1989. Retention and transport of nutrients in a third order stream: hyporheic processes. Ecology 70:1893-1905.

Triska, F. J., J. R. Sedell, K. Cromack, S. V. Gregory, and F. M. McCorison. 1984. Nitrogen budget for a small coniferous forest stream. Ecological Monographs 54:119-140.

Valett, H. M., J. A. Morrice, C. N. Dahm, and M. E. Campana. 1996. Parent lithology, surface-groundwater exchange, and nitrate retention in headwater streams. Limnology and Oceanography 41:333-345.

Velbel, M. A. 1988. Weathering and soil-forming processes. Pages 93-102 in W. T. Swank and D. A. Crossley, editors. Forest ecology and hydrology at Coweeta. Springer-Verlag, New York, New York, USA.

Vitousek, P. M., J. D. Aber, R. W. Howarth, G. E. Likens, P. M. Matson, D. W. Schindler, W. H. Schlesinger, and D. G. Tilman. 1997. Human alteration of the global nitrogen cycle: sources and consequences. Ecological Applications 7:737-750.

Wagener, S. M., M. W. Oswood, and J. P. Schimel. 1998. Rivers and soils: parallels in carbon and nutrient processing. BioScience 48: 104-108.

Webster, J. R., and T. P. Ehrman. 1996. Solute dynamics. Pages 145-160 in F. R. Hauer and G. A. Lamberti, editors. Methods in stream ecology. Academic Press, San Diego, California, USA.

Webster, J. R., J. L. Meyer, J. B. Wallace, and E. F. Benfield. 1997. Organic matter dynamics in Hugh White Creek, Coweeta Hydrologic Laboratory, North Carolina, USA. Journal of the North American Benthological Society 16:74-78.

Webster, J. R., and B. C. Patten. 1979. Effects of watershed perturbation on stream potassium and calcium dynamics. Ecological Monographs 49:51-72.

Wood, E. D., F. A. J. Armstrong, and F. A. Richards. 1967. Determination of nitrate in seawater by cadmium-copper reduction to nitrite. Journal of the Marine Biological Association of the United Kingdom 47:23-31.

Zar, J. H. 1984. Biostatistical analysis. Prentice Hall, Englewood Cliffs, New Jersey, USA.

\section{APPENDIX A}

A table showing the results of transient storage modeling is available in ESA's Electronic Data Archive: Ecological Archives E086-130-A1.

\section{APPENDIX B}

A table showing the nutrient concentrations in laboratory microcosms is available in ESA's Electronic Data Archive: Ecological Archives E086-130-A2.

\section{APPENDIX C}

A figure showing change in dissolved organic nitrogen (DON) and dissolved organic carbon (DOC) in laboratory microcosms is available in ESA's Electronic Data Archive: Ecological Archives E086-130-A3. 